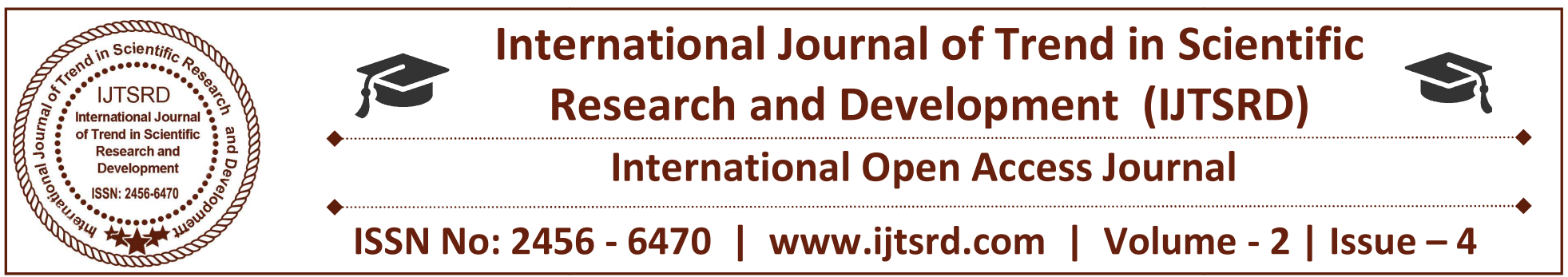

\title{
A Comparative Study on Agricultural Crop Disease Detection Systems
}

\author{
Sneha N, Thota Santosh, C R Manjunath \\ Department of Computer Science and Engineering \\ School of Engineering and Technology, Jain University, Bengaluru, Karnataka, India
}

\begin{abstract}
Agriculture is a widely practiced profession. During cultivation of crops taking sufficient care of the crops is very necessary. A variety of fungi and bacterial diseases affect the crop in growth. Early diagnosis and detection of crop diseases leads to an increased yield of crops. For this reason, a lot of researches have been going on worldwide to develop systems that are efficient and feasible in agricultural crop disease detection. Thus, it has been an interesting area of research. So, we carry out a thorough study of around 13 papers and various other articles, covering disease detection systems on rice, wheat, paddy, cucumber and grapes. Also, we try to present a comparative study based on the criteria Methodology.
\end{abstract}

Keywords: Agriculture; image processing; support vector machine; neural networks classifier

\section{INTRODUCTION}

Agriculture provides employment to a large population of the world. Also, agricultural products are the primary need of every citizen. The world population is increasing at a very fast rate approx. 83 million per year. This has also increased the need for supply of food crops to fulfil the hunger of the increased population. The study of agriculture, known as the agricultural sciences has led to a lot of development in this field like, scientific farming, use of high end technology in growing crops etc. All this progress with agriculture has also led improved quality and quantity of food products.

The major categories of agricultural crops include Cereals (barley, maize, wheat, rice etc), Roots and Tubers (cassava, potatoes), Sugar crops (sugarcane etc), Pulses (lentils, peas, dry beans etc), Vegetables (onions, cabbage chillies, lettuce etc), Fruits (Mango, apples, oranges etc), Nuts (cashew nuts, almonds etc), Oil-bearing plants (Sunflower, mustard), Fibers (Jute, cotton etc), Spices (anise, pepper, nutmeg etc) and others (tea, coffee etc)[13]. 
Here we present regional cropping patterns across the globe:

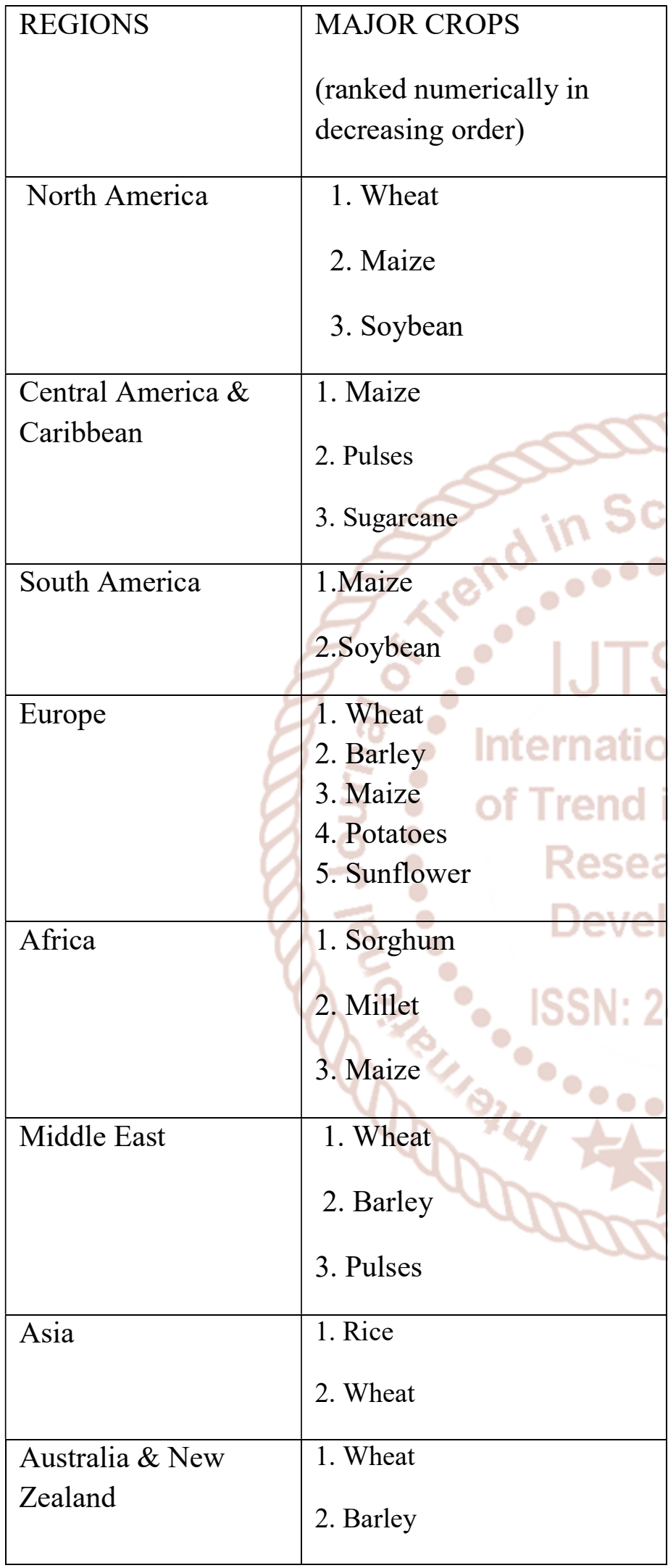

Table 1.1 Regional cropping patterns

Even with all this progress slowly, this charm of agricultural field with its lush green crop fields is being lost. This is due to rapid industrialization, better monetary opportunities in urban India etc. Agriculture as a profession has not been giving sufficient results due to crop loss, drought, unseasonal rainfall etc. In this research, we try to address one issue crop loss due to disease infection.

Disease detection and treatment at the right time is very necessary. Disease detection requires a great in depth knowledge of various diseases and their visual symptoms. It is practically impossible for a beginner to learn all this. Also, with manual detection only a limited number of conventional diseases can be detected, as the knowledge of such diseases is usually passed from older generations. The farmers would have little or no idea about the new diseases that are being discovered every new day. Any wrong detection of crop disease would be a great loss to the farmer as well as the country's GDP.

To overcome such problems various researchers across the globe are working on inventing new systems that use modern image processing and AI technologies to that aid the farmers in better detection of crop diseases. Usually what happens in a computerized crop disease detection system is that the image of the disease is captured through a camera, then various pre-processing techniques like segmentation etc are applied to separate the disease area and then machine learning or AI techniques are applied to classify the diseases.[1]

In this research we try to compare two different families of crops i.e., climbers and non-climbers with respect to their disease detection methodologies, the accuracy a particular methodology gives etc. 


\section{BACKGROUND WORK}

A lot of systems in plant disease detection follow some general principles/steps:

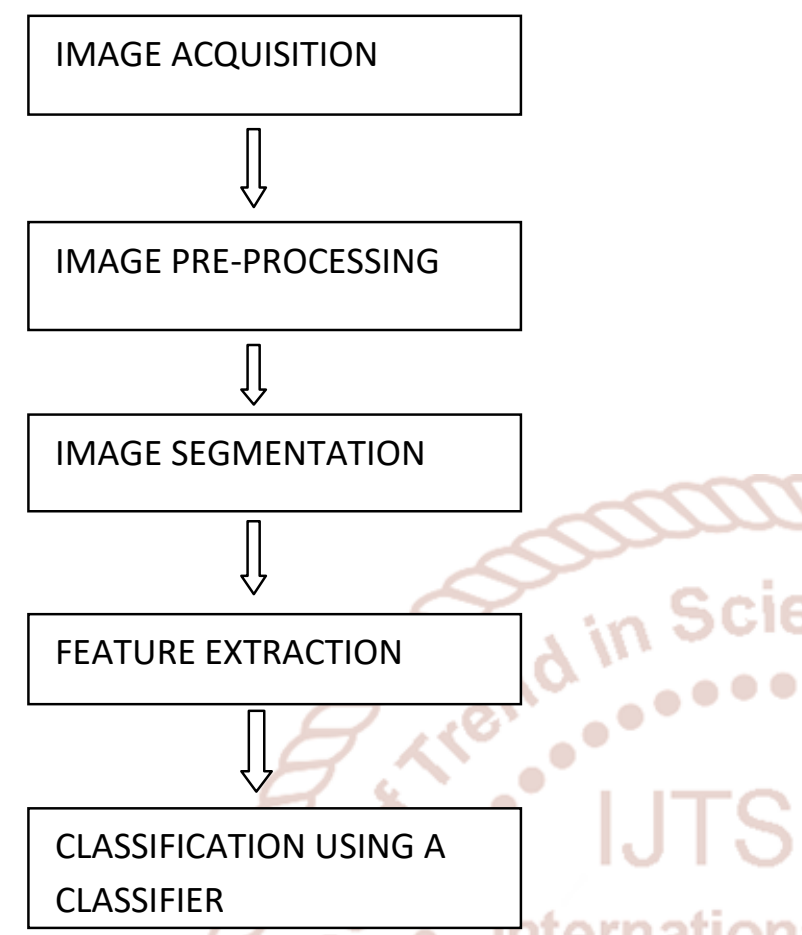

Figure 1. Flow diagram of a plant disease detection system

1. Image Acquisition:

A good quality digital camera is used to capture pictures from the agricultural fields.

Some of the well known cameras used for this purpose are Nikon D80, |GSNikon Coolpix P4 [10].

2. Image Pre-processing:

De-noising is the major operation performed here. The salt and pepper noise which is the most common type of noise can be removed by a median filter [11]. Contrast enhancement, shadow effect removals are some other operations performed.

\section{Image Segmentation:}

Segmenting the image into different regions and parts is called image segmentation. The image is partitioned either monitoring sudden changes in intensity values (edge detection etc) or using a particular criteria (Otsu's algorithm)[10]. Kmedoid can also be used as it is more robust in the presence of noise or outlines [11].

\section{Feature Extraction:}

This refers to extracting important features representing an object. Colour, shape and texture are important features extracted [10]. Shape features include area, axis, angle etc [10].

\section{Classification:}

It is a supervised learning approach. In this, a set of training data is fed to the disease detection system, which "learns from" the data which has been specifically labelled. Later, the test data is fed to test the accuracy of the system. The end result would be that the disease would be classified according to the features extracted.

There have been many systems developed to detect diseases in plants. Some implementations are described here:

In [1], S.Phadikar et al have implemented a rice disease detection system. Here they were mainly focussing on detecting "blast" and "brown spot" disease. For this they have used Nikon COOLPIX P4 for image acquisition. Mean filter was used for image enhancement and Otsu's threshold based segmentation was used for image segmentation. In the detection level, the first stage of classification between uninfected and diseased leaves was based on the number of peaks in the histogram, and in the second stage SVM and Baye's classifiers were applied to classify leaf diseases.

In [2], Amrita A. Joshi et al have developed a system that detects Rice Bacterial Blight, Rice Blast, Rice Brown Spot, Rice Sheath Rot diseases. The feature extraction step extracted colour and shape features. Knearest neighbour and Mean Distance Classifier have been used to classify the diseased leaves.

In [3], Radhika Deshmukh et al have developed a system for detecting paddy blast, brown spot paddy spot and normal paddy in paddy leaves. The k-means clustering algorithm has been used for segmentation of the image which gave best results at 3 clusters. Back propagation neural network was used to classify the diseases.

In [4], Varsha P. Gaikwad et al have developed a system to detect wheat leaf diseases.

Canon A3500 was used to acquire the images and subtraction technique was used to suppress the background of the images. $\mathrm{K}$ means algorithm was used for segmentation of the image. Texture, colour and shape were features extracted. Two classifiers: 
Neural Networks(for texture, color and shape) and Support Vector Machine(SVM) (for texture and shape).

In [5] Pooja Pawar et al have implemented a cucumber disease detection system for downy mildew and powdery mildew diseases. The first order statistical moments(kurtosis and skew) and second order statistical moments(Grey level co-occurrence matrix) are used to extract features. Artificial Neural Network is used to classify the diseases.

In [6], P. Krithika et al have developed a system for disease detection in cucumber leaves. Image Resizing, contrast enhancement and colour space conversion and various other pre-processing functions were performed. K-means algorithm was used for segmentation and features from these segments were extracted using Grey level co-occurrence matrix. A supervised classification technique Multiclass Support Vector Machine (SVM) is used as a classifier.

In [7], A.Meunkaewjinda et al have devised a system for grape leaf disease detection.

The unsupervised SOFM network is used cluster the color pixels to obtain the groups of colours in the image. The back propagation neural network is used to obtain grape leaf color from the background. SVMs are used for grape disease classification.

In [8], Sanjeev S Sannakki et al have devised a method to detect grape leaf diseases.

A background removal process is applied, and then 5 iterations of Anisotropic diffusion is applied to enhance the image. K-means clustering is used to segment the image. Best results were obtained at 6 clusters. The Grey level co-occurrence matrix is used for feature extraction. A feed forward Back Propagation neural network is used for classification.

In [9], Pranjali B. Padol et al implemented a methodology to detect grape leaf diseases. The noise in the acquired image is reduced using Gaussian Filters and $\mathrm{K}$ - means algorithm is used for image segmentation. System color and Texture features were extracted. The Linear Support Vector Machine is used to classify the diseases.

\section{THE COMPARATIVE STUDY}

Climbers are plants with weak roots that need the support of other objects or plants to grow. Hence they tend to grasp/hold other objects as a support for their growth. They are usually vines that twine around trees for growth. Climbing plants are usually divided into two groups- Bines and the Vines. Here cucumber (cucumis sativus) and grape (vitis vinifera) which are both climbers have been used for our study.

Our references to non climbing plants refers to any crop/plant that grows above or below the soil but doesn't take support of external objects for its growth. Its root is strong and provides all necessary support for the growth of the plants vertically. Some examples of non-climbers are millet, rice, ragi, wheat, pulses, sugarcane, maize etc. Here we have used rice (Oryza sativa) and wheat (Triticum) for our study.

The two classification techniques used are - support vector machine(svm) and neural network classifier.

Wheat with svm as a classifier achieves a highest accuracy of $89.23 \%$ with pre-processing done with median filter, segmentation done using K-means and features extracted were texture, color, shape. And with neural network as a classifier highest accuracy of 98.3\% was achieved with median filter for preprocessing, Otsu's thresholding and morphological operator for segmentation.

Rice with svm as a classifier achieved a highest accuracy of $97.2 \%$ using median filter for preprocessing. Color and outline spotting were used to segment disease area.

Grape with svm as a classifier achieved a highest accuracy of $89.23 \%$ using anisotropic diffusion technique for pre-processing. Here back propagation neural network was used for segmentation. And with neural network as a classifier highest accuracy of $89.17 \%$ with thresholding and gaussian filter for preprocessing and k-means for segmentation. Here we present a comparative study of the same. 


\begin{tabular}{|c|c|c|c|c|c|c|c|c|c|c|}
\hline \multirow{2}{*}{$\begin{array}{c}\text { Classificati } \\
\text { on } \\
\text { Technique }\end{array}$} & \multicolumn{2}{|c|}{$\begin{array}{l}\text { Climber } \\
\text { Family }\end{array}$} & \multicolumn{2}{|c|}{$\begin{array}{l}\text { Non-climber } \\
\text { Family }\end{array}$} & \multirow{2}{*}{$\begin{array}{l}\text { Accur } \\
\text { acy } \\
(\%)\end{array}$} & \multirow{2}{*}{$\begin{array}{c}\text { No. of } \\
\text { Samp } \\
\text { les }\end{array}$} & \multirow[b]{2}{*}{$\begin{array}{c}\text { Focused } \\
\text { On }\end{array}$} & \multicolumn{3}{|c|}{ Methodology } \\
\hline & $\begin{array}{l}\text { Gra } \\
\text { pe }\end{array}$ & $\begin{array}{l}\text { Cucu } \\
\text { mber }\end{array}$ & $\begin{array}{l}\text { Whe } \\
\text { at }\end{array}$ & Rice & & & & $\begin{array}{c}\text { Pre- } \\
\text { processing }\end{array}$ & $\begin{array}{c}\text { Segmentat } \\
\text { ion }\end{array}$ & $\begin{array}{c}\text { Feature } \\
\text { Extraction }\end{array}$ \\
\hline \multirow{7}{*}{$\begin{array}{l}\text { Support } \\
\text { Vector } \\
\text { Machine }\end{array}$} & & & $\nabla$ & & 89.23 & 120 & Not specified & $\begin{array}{c}\text { Median } \\
\text { filter }\end{array}$ & $k$-means & $\begin{array}{c}\text { Texture, } \\
\text { color, shape }\end{array}$ \\
\hline & $\nabla$ & & & & 88.33 & 137 & $\begin{array}{c}\text { Downy, } \\
\text { Powdery } \\
\text { mildew }\end{array}$ & $\begin{array}{l}\text { Thresholdin } \\
\mathrm{g} \text { Gaussian } \\
\text { filter }\end{array}$ & k-means & $\begin{array}{l}\text { Texture, } \\
\text { color }\end{array}$ \\
\hline & & & & $\nabla$ & 92.06 & $\begin{array}{c}\text { Not } \\
\text { specifi } \\
\text { ed }\end{array}$ & $\begin{array}{c}\text { Brown spot, } \\
\text { Leaf blast, } \\
\text { Bacterial } \\
\text { blight }\end{array}$ & $\begin{array}{c}\text { Contrast } \\
\text { enhancemen } \\
t\end{array}$ & K-means & $\begin{array}{l}\text { Texture, } \\
\text { color, shape }\end{array}$ \\
\hline & & & & Q & 97.2 & 216 & $\begin{array}{c}\text { Bacteria-l } \\
\text { leaf, sheath } \\
\text { blight, rice } \\
\text { blast }\end{array}$ & $\begin{array}{c}\text { Median } \\
\text { filter }\end{array}$ & $\begin{array}{c}\text { Spot color } \\
\text { and outline } \\
\text { to segment } \\
\text { disease spot } \\
\text { area } \\
\end{array}$ & $\begin{array}{l}\text { Shape, } \\
\text { texture }\end{array}$ \\
\hline & $\varnothing$ & & & & 88.89 & 137 & $\begin{array}{l}\text { Downy, } \\
\text { Powdery } \\
\text { Mildew }\end{array}$ & $\begin{array}{c}\text { Thresholdin } \\
\mathrm{g} \\
\end{array}$ & $k$-means & $\begin{array}{l}\text { Color, } \\
\text { texture }\end{array}$ \\
\hline & 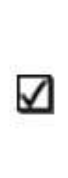 & & & & 89.23 & 1000 & Not specified & $\begin{array}{l}\text { Anisotropic } \\
\text { diffusion } \\
\text { technique }\end{array}$ & $\begin{array}{c}\text { Back } \\
\text { Propagation } \\
\text { Neural } \\
\text { Network } \\
\text { (BPNN) }\end{array}$ & Color \\
\hline & & 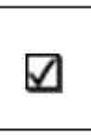 & & & $\begin{array}{c}\text { Not } \\
\text { specifie } \\
\text { d }\end{array}$ & $\begin{array}{l}\text { Not } \\
\text { specifi } \\
\text { ed }\end{array}$ & $\begin{array}{c}\text { Leaf spot } \\
\text { disease, leaf } \\
\text { miner, CMV } \\
\text { of cucumber } \\
\end{array}$ & $\begin{array}{c}\text { Contrast } \\
\text { enhancemen } \\
t\end{array}$ & k-means & $\begin{array}{c}\text { Gray level } \\
\text { co- } \\
\text { occurrence } \\
\text { matrix } \\
\end{array}$ \\
\hline \multirow{8}{*}{$\begin{array}{l}\text { Neural } \\
\text { Network }\end{array}$} & & & & $\nabla$ & $\begin{array}{c}\text { Not } \\
\text { specifie } \\
\text { d }\end{array}$ & $\begin{array}{l}\text { Not } \\
\text { specifi } \\
\text { ed }\end{array}$ & $\begin{array}{l}\text { Paddy blast, } \\
\text { brown spot }\end{array}$ & $\begin{array}{l}\text { Resizing of } \\
\text { image }\end{array}$ & k-means & $\begin{array}{c}\text { Gray Level } \\
\text { Co- } \\
\text { occurrence, } \\
\text { Discrete } \\
\text { wavelet } \\
\text { transform } \\
\end{array}$ \\
\hline & & & & $\nabla$ & $\begin{array}{c}\text { Not } \\
\text { specifie } \\
\text { d }\end{array}$ & 350 & $\begin{array}{l}\text { Rice blast, } \\
\text { nice brown } \\
\text { spot }\end{array}$ & $\begin{array}{c}\text { Not } \\
\text { specified }\end{array}$ & $\begin{array}{c}\text { Entropy } \\
\text { based bi- } \\
\text { level } \\
\text { thresholdin } \\
\text { g }\end{array}$ & $\begin{array}{l}\text { Region } \\
\text { segmentatior } \\
\text {, boundary } \\
\text { detection, } \\
\text { spot } \\
\text { detection of } \\
\text { image }\end{array}$ \\
\hline & & & $\nabla$ & & 80.21 & 120 & Not specified & $\begin{array}{c}\text { Median } \\
\text { filter }\end{array}$ & k-means & $\begin{array}{c}\text { Texture, } \\
\text { color, shape }\end{array}$ \\
\hline & $\nabla$ & & & & 100 & 33 & Not specified & $\begin{array}{l}\text { Thresholdin } \\
\text { g\& } \\
\text { Anisotropic } \\
\text { diffusion }\end{array}$ & k-means & Texture \\
\hline & & 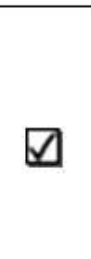 & & & 80.45 & $\begin{array}{l}\text { Not } \\
\text { specifi } \\
\text { ed }\end{array}$ & Not specified & $\begin{array}{l}\text { No } \\
\text { preprocessin } \\
\text { g technique }\end{array}$ & $\begin{array}{c}\text { Mean, } \\
\text { standard } \\
\text { deviation, } \\
\text { variance, } \\
\text { gray level } \\
\text { co- } \\
\text { occurrence } \\
\text { matrix }\end{array}$ & Texture \\
\hline & & & $\nabla$ & & 98.3 & $\begin{array}{l}\text { Not } \\
\text { specifi } \\
\text { ed }\end{array}$ & $\begin{array}{l}\text { Fungal } \\
\text { disease }\end{array}$ & $\begin{array}{l}\text { Median } \\
\text { filter }\end{array}$ & $\begin{array}{c}\text { Otsu } \\
\text { thresholdin } \\
\text { g. } \\
\text { morphologi } \\
\text { cal operator }\end{array}$ & $\begin{array}{l}\text { Texture, } \\
\text { color, shape }\end{array}$ \\
\hline & & $\nabla$ & & & 82.3 & $\begin{array}{c}\text { Not } \\
\text { specifi } \\
\text { ed }\end{array}$ & $\begin{array}{c}\text { Viral } \\
\text { diseases }\end{array}$ & $\begin{array}{l}\text { Image } \\
\text { shifting, } \\
\text { rotating, } \\
\text { mirroring }\end{array}$ & $\begin{array}{c}\text { Not } \\
\text { specified }\end{array}$ & Sensitivity \\
\hline & $\nabla$ & & & & 89.17 & 137 & $\begin{array}{l}\text { Down, } \\
\text { Powdery } \\
\text { mildew }\end{array}$ & $\begin{array}{l}\text { Thresholdin } \\
\text { g. Gaussian } \\
\text { filter }\end{array}$ & k-means & $\begin{array}{c}\text { Texture, } \\
\text { colour }\end{array}$ \\
\hline
\end{tabular}

Table 4.1 Comparison between Climbers and Non-Climbers 


\section{CONCLUSION}

Plant diseases can occur due to a variety of reasons and they cause a great amount of loss in agriculture if enough care is not given. Today as we have made great progress in technology, the benefits of faster and efficient technology has been used to develop automated disease detection system which effectively notify the care takers about the diseases. In this same direction, we have tried to provide our contributions by studying various such systems that have been developed using image processing and machine learning technologies. This study summarized and compared various image processing and machine learning techniques i.e., image segmentation, feature extraction and classification that have been used in disease detection. And hence, here we have shown how a combination of image processing and machine learning techniques can be used to aid the improved quality and quantity of agricultural produce.

\section{REFERENCES}

1) S. Phadikar, J. Sil, and A. K. Das, "Classification of Rice Leaf Diseases Based on Morphological Changes", International Journal of Information and Electronics Engineering, Vol. 2, No. 3, May 2012

2) B.D. Jadhav, Amrita A. Joshi, "Monitoring and Controlling Rice Diseases Using Image Processing Techniques", 2016 International Conference on Computing, Analytics and Security Trends (CAST) College of Engineering Pune, India. Dec 19-21, 2016.

3) Radhika Deshmukh, ManjushaDeshmukh, "Detection of Paddy Leaf Diseases", International Journal of Computer Applications (0975 - 8887) International Conference on Advances in Science and Technology 2015 (ICAST 2015).

4) Varsha P. Gaikwad, Dr. Vijaya Musande, "Wheat Disease Detection Using Image Processing", 9781-5090-4264-7/17/\$31.00@2017 IEEE.

5) Pooja Pawar, Varsha Turkar, Pravin Patil, "Cucumber Disease Detection Using Artificial

a. Neural Network".

6) P Krithika and S Veni, "Leaf Disease Detection using Multiclass Support Vector Machine", IEEE WiSPNET 2017 conference.
7) A.Meunkaewjinda, P.Kumsawat, K .Attakitmongcol, A.Srikaew, "Grape Leaf Disease Detection from colour imagery using hybrid intelligent system", Proceedings of ECTICON 2018.

8) Sanjeev S Sannakki, Vijay S Rajpurohit, V B Nargund3, Pallavi Kulkarni, "Diagnosis and Classification of Grape Leaf Diseases using Neural Networks", 4th ICCCNT 2013 July 4-6, 2013, Tiruchengode, India.

9) Pranjali B. Padol, Prof. Anjali A. Yadav, "SVM Classifier Based Grape Leaf Disease Detection", 2016 Conference on Advances in Signal Processing (CASP) Cummins College of Engineering for Women, Pune. Jun 9-11, 2016.

10) Jitesh P. Shah, Harshadkumar B. Prajapati, Vipul K. Dabhi, "A Survey on Detection and Classification of Rice Plant Diseases", 2016 IEEE.

11) Prof. Atul Shire, Prof. Umesh Jawarkar, Mr. Manoj Manmode, "A Review Paper On: Agricultural Plant Leaf Disease Detection Using Image Processing", IJISET - International Journal of Innovative Science, Engineering \& Technology, Vol. 2 Issue 1, January 2015.

12) Qing Yao, Zexin Guan, Yingfeng Zhou, Jian Tang, Yang $\mathrm{Hu}$, Baojun Yang, "Application of support vector machine for detecting rice diseases using shape and color texture features", 2009 International Conference on Engineering Computation.

13) Billie Leff, Navin Ramankutty, and Jonathan A. Foley, "Geographic distribution of major crops across the world", Global Biogeochemical Cycles, vol. 18, gb1009, doi:10.1029/2003gb002108, 2004

14) S.D.Khirade and A.B.Patil , 2015, February. Plant Disease Detection Using Image Processing. In International Conference on Computing Communication Control and Automation (ICCUBEA), 2015 (pp. 768- 771). IEEE.

15) A. K. Singh, A. Rubiya, B. S. Raja,,"classification of rice disease using digital image processing and svm," International Journal of Electrical and Electronics Engineers, vol. 07, no. $01,2015$.

16) T. Suman and T. Dhruvakumar, "classification of paddy leaf diseases using shape and color features," vol. 07, no. 01, pp. 239-250, 2015. 